http://artnodes.uoc.edu

\title{
Memory as Material - a visual arts research practice in neuroscientific laboratories*
}

\author{
Maria Manuela Lopes \\ Visual artist and Postdoctoral researcher \\ ID+ Instituto de Investigação em Design Media e Cultura (Universidade de Aveiro) \\ Instituto de Biologia Molecular e Celular (Universidade do Porto, Portugal)
}

Submission date: October, 2015

Accepted date: October, 2015

Published in: November, 2015

\begin{abstract}
In order to critically explore memory as material for art practice, I take my experience of an artistic residency in a neuroscience laboratory as a starting point to consider artistic encounters with distinct fields of research and matter. I explore my practice-based projects developed progressively through a body of interrelated installation artworks intertwined with the theme of memory. The residencies at different laboratories were performed under research methods familiar to my practice and an ethnographic approach has been used, with studio work mirroring an evolving embedded research process from fieldwork. The sample $\mathrm{PhD}^{1}$ constructs connections between visual art practice and neuroscientific research studies in the field of Alzheimer's disease (AD). The aim was to explore the representational strategies of AD studies in the laboratory through art practice, alluding to the (dys) functioning of autobiographical memory. The practice explored concepts of the material and immaterial, matter and code, the real and the imaginable, body and metaphor. Debates on visuality and 'looking at', the institutional gaze and the technology within which the visual and science are rooted, are examined using Foucault's concept of panopticon and Latour's actor-network theory.
\end{abstract}

* This research was funded by grants from the FCT - Portuguese Foundation for Science and Technology (SFRH/BD/37721/2007 and SFRH/BPD/98356/2013).

1. M. Lopes (2013). 


\section{artnodes}

http://artnodes.uoc.edu

Memory as Material - a visual arts research practice...

In creative terms, this exploration allowed the development of several novel and unique methods of research, the resulting artefacts, and the practical materialization of these via the agency of installation. This article suggests that, while exploring a space for art practice within the discourse of memory embedded in scientific laboratories and medical practices dealing with the network of people involved, I have gained a space within the discourse on mind, memory and matter.

\section{Keywords}

memory, matter, arts-led research, neuroscience, installation, Alzheimer's disease

\section{La memoria como material: una práctica de investigación sobre las artes visuales en los laboratorios neurocientíficos}

\section{Resumen}

Con el objetivo de explorar de forma crítica la memoria como material para la práctica artística, tomo mi experiencia de una estancia artística en un laboratorio de neurociencias como punto de partida para considerar encuentros artísticos con distintos campos de investigación y contenido. Exploro mis proyectos basados en la práctica y desarrollados de forma progresiva a través de un cuerpo de obras de arte basadas en instalaciones interrelacionadas, entrelazadas con los temas de la memoria. Las estancias en distintos laboratorios han sido respaldadas por métodos de investigación familiares a mi práctica y se ha empleado un enfoque etnográfico, con un trabajo de estudio que refleja un proceso de investigación integrado de trabajo de campo en evolución. El doctorado de ejemplo² construye conexiones entre la práctica artística visual y los estudios de investigación neurocientífica en el campo de la enfermedad de Alzheimer (EA). El objetivo era explorar las estrategias figurativas de los estudios de EA en el laboratorio a través de la práctica artística, aludiendo a la disfunción de la memoria autobiográfica. Los conceptos prácticos explorados de lo material e inmaterial, el contenido y el código, lo real y lo imaginable, el cuerpo y la metáfora. Los debates sobre la visualidad y la observación, la mirada institucional y la tecnología en la que se basan lo visual y la ciencia se examinan utilizando el concepto de Foucault de panopticón y la teoría de red-actor de Latour.

En términos creativos, esta exploración permitió el desarrollo de varios métodos de investigación únicos y novedosos, los artefactos resultantes y la materialización práctica de estos a través de la instalación. Este artículo sugiere que al explorar un espacio para la práctica artística en el discurso de la memoria integrada en laboratorios científicos y prácticas médicas tratando con la red de personas implicadas, he ganado un espacio en el discurso de la mente, la memoria y el contenido.

\section{Palabras clave}

memoria, contenido, investigación artística, neurociencia, instalación, enfermedad de Alzheimer 


\section{artnodes}

http://artnodes.uoc.edu

Memory as Material - a visual arts research practice...

\section{Introduction}

In my research process, I have documented the assessment and categorization of Alzheimer's patients and their exposure to various therapies. I have also documented molecular and cellular research laboratory procedures and collected laboratory materials. In order to maintain a common thread when approaching these spaces, methods have focused on neuroscientific diagnostic images (MRI and PET scans), graphs, diagrams, notes, models, photographs, instruments, physical space conditions and hybrid forms of these, and establishing a critical link to art practice (Figure 1). In laboratory studies, these visual approaches are referred to as representational strategies or practices (Lynch and Woolgar, 1990: 1-18).

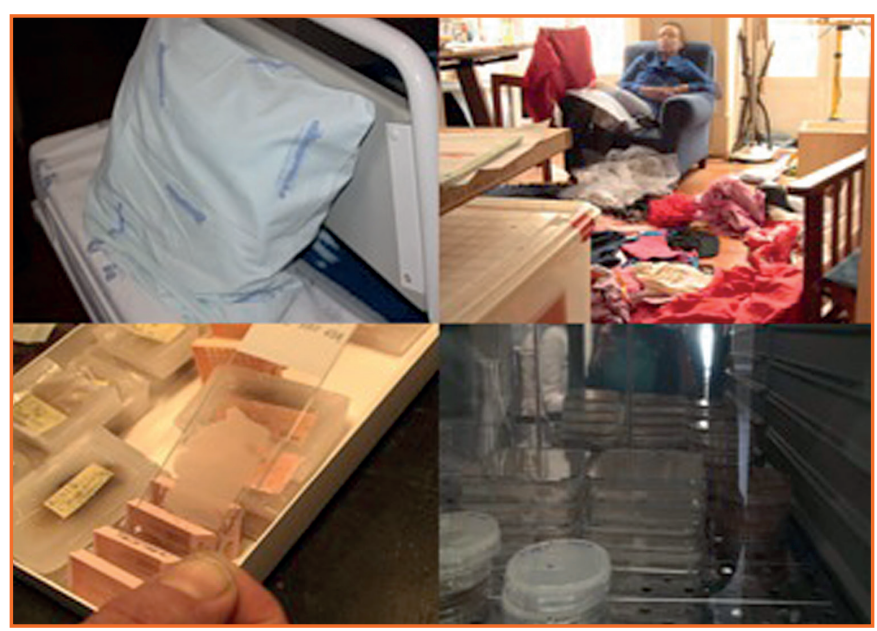

Figure 1. 'The four virtual archival spaces.' Source: Lopes (2009)

The late or scarce physical symptoms of Alzheimer's disease prompted my interest in how the intermediation of the technological image is a substitute for clinical sensorial examination of the body as far as some are concerned, and how certain laboratory practices turn the biological materiality of the loss of memory into a visible phenomenon. In clinical practice, perspectives similar to those adopted by Jonathan Crary (1992) or Sturken and Cartwright (2002) assume a supposed neutrality of the technologies and ascribe objectivity, methodological consistency and precision to the images. Representation is the substitute for symptoms and behaviours reported by the patient. Images are seen as essential to systems of power and concepts of knowledge and self-regulation. Michel Foucault (1995) uses a powerful metaphor to explain this idea: the panoptic prison functioning as a reminder of the permanent exposure to visibility to which one is subjected from then onwards. As Foucault suggests, scientific and medical understanding of the body focuses on surveillance using practices of assessing, recording and archiving to classify and define the boundaries between illness and health.
An apparent organization of the sensorial perception of space and time thus articulates power relationships. According to Sturken and Cartwright (2002), this act of looking is linked to other activities that ascribe meaning to what vision uncovers, such as experimenting, measuring, analysing and ordering. My practice uses a similar approach to deal with the reorganization of materials, space and time around the study of Alzheimer's. The panoptical gaze surveys the human body which, for the purposes of the clinical investigation, becomes transparent; the invisible disease becomes accessible; volumes, spaces and time become visible in representational strategies, both portable and able to be juxtaposed in a translation format. Vision prevails but is dependent on other sensory and cognitive processes, and also on context.

The relationship between vision, technology, science and nature is explored in Bruno Latour and Steve Woolgar's seminal study of 'laboratorial life' (1986), and Latour's studies on action in science. Latour (1986) suggests that science is a process of addition of inscriptions, which primarily works through study of images, graphs, maps, tables and text data rather than the real phenomena. He emphasizes the advantage given by such images and inscriptions over scientific claims, with a focus on the whole process of mobilization surrounding their production. Latour (1987) emphasizes the central role played by images such as inscriptions and material artefacts in consolidating the networks established between the laboratory and the outside community.

\section{The Approach}

The way in which we see, hear, feel or pay attention to something depends largely on where we are. It is not just that 'representations of the body' change historically: the material body itself is necessarily entangled in the complex web that is, in part, historical. Thus, the body and perception were subject to investigation, regulation and discipline throughout the $19^{\text {th }}$ Century, as Foucault has shown. Perception, or reception, of the world as an image, according to Crary $(1992,1999)$, corresponds in a synchronized and complementary way to a condition that is the perception of their own body as an image. It may therefore be said that the body was invented as a theoretical object at the beginning of the $20^{\text {th }}$ Century, as outlined in Foucault's Birth of the Clinic (2003), which analysed the body as the object of observation, investigation, classification and regulation.

Memory is constructed of many fragments, types, systems and processes. Through this work, I suggest that the assembly may evoke this through the use of overlapping, juxtaposition, edition and installation practices. Images circulate through different contexts (enactment of the archive) and undergo some ordering and editing processes in the studio as a reflection of the capacity of memory to reconstruct lived events from archived cues of sensuous impressions, 


\section{artnodes}

http://artnodes.uoc.edu

feelings, context and time (re-enactment of the archive). The Approach (Figure 2) explores assembly and movement of images and experiences between the various spaces, whether organized and almost aseptic (the laboratory or the gallery) or highly emotional and almost chaotic (the hospital and the studio).

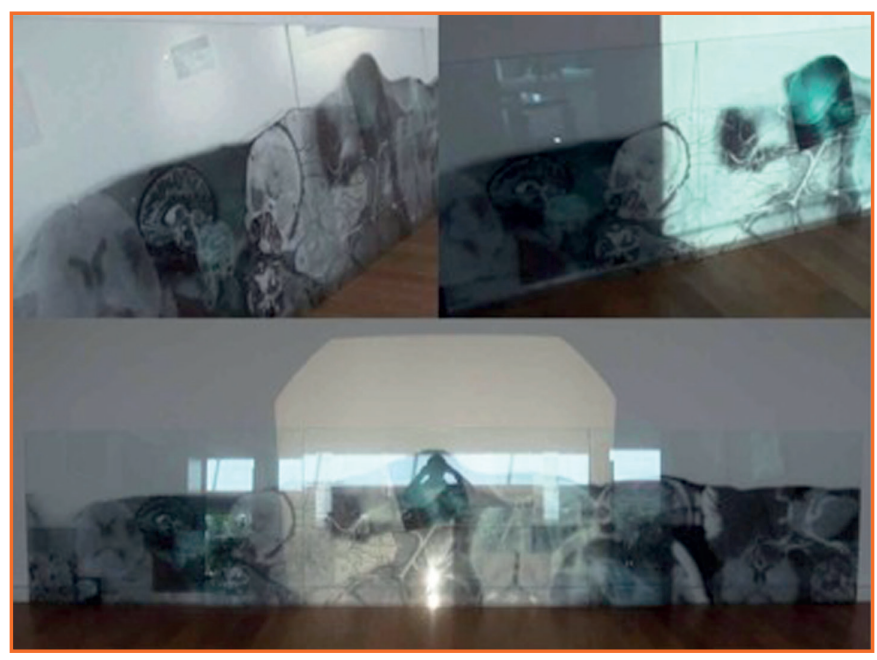

Figure 2. The Approach. Exhibition A Arte do Cérebro, Centro Cultural da Figueira da Foz. Source: Lopes, 2009

Throughout the installation and research process, attention has been paid to the way in which particular materials (eg, glass and colour) support specific qualities of engagement, and considerable energy has been invested in the exploration of light and reflection in an attempt to reflect Latour's understanding that memory, as research, functions in a network of systems and processes.

\section{The Archive}

My concept of the archive departs from the understanding of Berg and Mol (1998) that medical and scientific investigation is based on practices of construction, assembly and incorporation of techniques, habits, ideas, images and conversations. The enactment of my archive depends on circulation through these real and virtual spaces, physical areas and conceptual domains, (Figure 3) in line with Silvia Casini's notion that an archive exists simultaneously in two formats:

firstly, as a physical space where artefacts and materials are collected and displayed according to certain criteria/rules in order to be accessible
Memory as Material - a visual arts research practice...

by visitors and users. Secondly, [...] [as] terms of discourse within a specific space, time and cultural location: it is 'the system that governs the appearance of statements' (Foucault, 1976, p. 12, cited in Casini, 2010: n. pag)

In this circulation, fragments or traces (Derrida, 2010) are both produced and collected, disrupting a temporal assumption that links the part to the whole through deferral, the past to the present. My copies of archival fragments of neuroscientific records or direct records of laboratory sessions relate to something other than themselves, thus functioning at the level of evocation or memory. Engaging with Michel Foucault's understanding of the archive in the medical arena, I explore how the archive $^{3}$ can establish a complex set of relations.

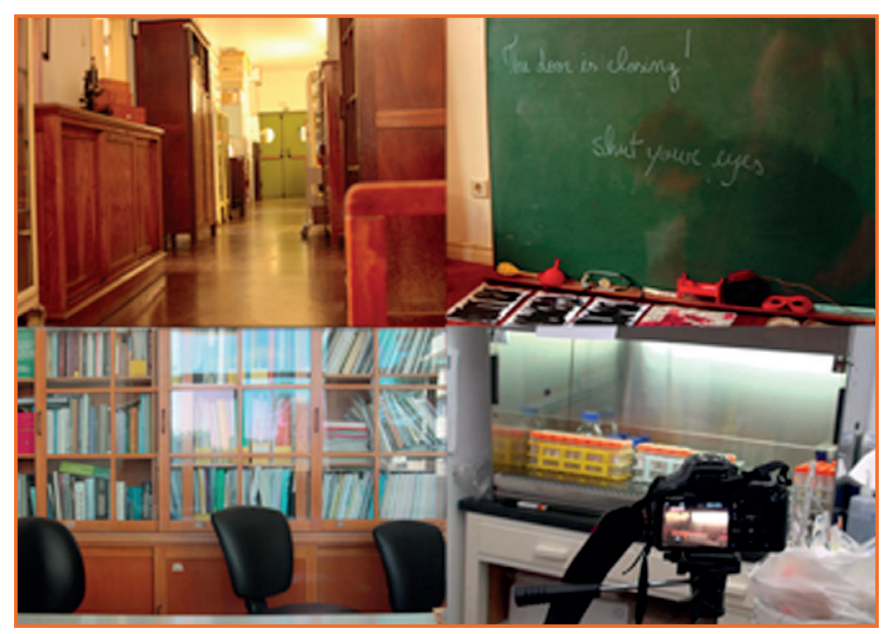

Figure 3. 'The four virtual archival spaces.' Source: Lopes, 2009

Within neurological discourse and practice, attempts are made to understand Alzheimer's disease through observation, visualization, and measuring and archiving methods. These ascribe meanings that are confined to specific areas of knowledge and therefore correspond to standard ways of understanding. These models of knowing are inaccessible to those outside the specific biomedical field and, I would argue, are opaque; they reflect socio-cultural norms and are thus unable to evoke the subject of memory. They also fail to reflect the agony of being lost in oneself, and the material reality of the bodily practices to which patients are subjected because they are perceived to be outside the norm.

Cultural representations of Alzheimer's disease usually appeal to the idea of the perfect model of care in the family or nursing home,

3. In terms of archiving, details of decisions concerning which materials were preserved or discarded prior to public access are often unavailable. The constitution and keeping of materials is subject to systems, schemas and structures of ordering and classification. Even cataloguing, which is designed to enable or restrict access, serves to emphasize some of the archive's contents, effectively marginalizing or excluding its remaining contents. 


\section{artnodes}

http://artnodes.uoc.edu

Memory as Material - a visual arts research practice...

showing elderly people supported by their families. These images are charged with emotion, compelling us to reflect on our own mortality and ethical values. Images in the medical arena, however, usually show the disease in terms of imaging technologies, invariably in fragments such as analyses of cells, brains, spinal fluid or blood. The patient is thus located in terms of the disease, stripped of identity and objectified. In recording laboratory data or copying MRI scans, ECGs or microscopic images, I am appropriating and re-contextualizing images as a familiar methodological tool. When confronted by patients' records, I am studying not an embodied, contextualized patient but a heterogeneous fragmentary compound of standardized information; a translation of the individual patient's crisis that is inaccessible to the non-specialist. The dependence on these technological viewings of the interior of the body in crisis for diagnosis and treatment (and in this case the discovery of new treatments) discourages looking at the patient's material body.

The Archive (Figure 4) is not a unitary installation work that can be reproduced in different contexts, but consists of multiple evolving works/exhibitions presented in different locations. Each venue provides access to different audiences using strategic modes of addressing. Objects taken directly from the scientific environment carry emotional and cultural emanations beyond their primary function; I attempt to expand on their power to extend their relationship to memory outside the frame of the official scientific record. Objects that I could not remove, such as props from the neuropsychology assessment kit, were replaced by similar things that I owned. My possessions provided useful material support for the self-assessment sessions, but

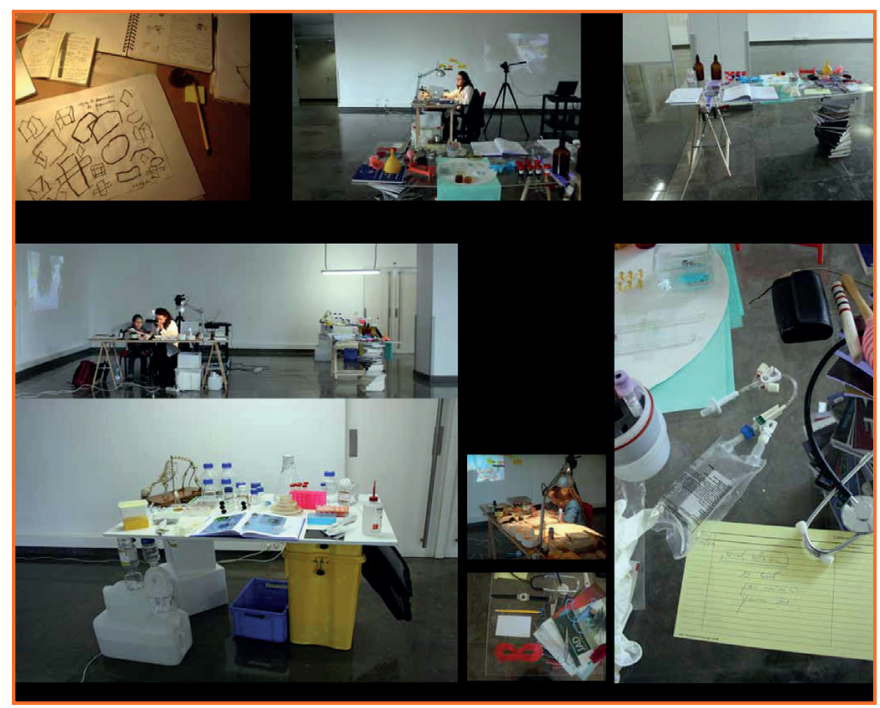

Figure 4. The Archive: Enactment/Re-Enactment of the Archive. Performance at IMM, 18-25 March. Source: Lopes (2011) somehow seemed too personal to be used to illustrate the memory discourse I was aiming for, since they belonged neither to the research context of Alzheimer's disease, nor to my studio space. Sketching and casting proved to be a valid way to mediate a form of experiencing and understanding them. A similar distance was achieved by editing videos or photographs used in the enactment of the archive as a documentary tool.

While The Approach provided a quasi-aseptic atmosphere of a subject explored at a distance - through glass, a lens, and white light - and provided a space for stillness and body/breath-focused reflection, The Archive relies on the chaotic material of fragments produced during the exploration of the settings, with all of the tensions and contradictory feelings of invasion or impotence experienced by the researcher or observer. Despite the emotional tension raised by immersion in the 'patient's space', the installation acknowledges the implicit regulatory power of the representational strategies in the construction of the archive, emphasizing certain parts and erasing or effacing others.

\section{The Assessment}

Medical and laboratorial practices associated with assessment conditions transform the biological materiality of memory loss into a visual phenomenon. I would argue that the visibility of loss of memory is constructed through space/time performances and objects in inverse proportion to autobiographical memory: the larger the accumulation of inscriptions constructing the patient via the representation of the body (Berg and Bowker, 1996, p. 4), the fewer their potential autobiographical memories.

In medical terms, assessment requires the visual identification of symptoms, confirmed by diverse material traces of the archive that may include detailed blood tests or MRI scan results. The final stage of assessment, the announcement (the call) of the specific category of the pathology, in oral and written forms, is a performance event that concludes one assessment cycle to start many others. It is no longer concerned with categorization but with the evolution and effect of possible therapies. It does not describe the patient, but the act of calling/writing has visible consequences and impacts on the patient's body and life, returning as further acts, interventions, and memories. The written notes thus reformulate the material body. ${ }^{4}$

As noted, medical assessment through visual evidence is associated with specific cultural practices and 'modes of seeing' (Sturken and Cartwright, 2002, chapter 8). Science has thus been interpreted as a process of generating 'drawings' that increasingly accumulate and circulate, rather than observing the natural world.

4. This formulation relates to theoretical proposals about the perception of scientific and clinical practice put forward by the scientific sociologist Bruno Latour. He observed how the materiality of the body of the patient is replaced by a collection of two-dimensional records that form an archive. 


\section{artnodes}

http://artnodes.uoc.edu

This clearly applies to medical practices represented by images and text, such as those discussed here, in which the performances behind their construction vanish like a memory event and are replaced by a diagram of the sensual path that the brain has experienced through that same time/place action. When these are published, shared in meetings and circulated in the media as 'immutable mobiles' (Latour, 1998, p. 426), these inscriptions become self-referential and evocative of other, previous representations rather than the messy, sensual material reality to which we belong.

Latour, Michael Callon and John Law devised what came to be known as the actor-network theory (ANT). They employ a broad definition of the 'social' that is taken to be the associations and web-like relationship between heterogeneous material elements in any situation. Scientific facts depend on the performances and actions of objects; Latour (2005) proposes that they should be part of the explanation and should not simply be merged into the logic and reasoning of scientists at work. The subject/object divide is not an issue; the aim is to 'learn from the actors' (Latour, 1999, p. 20) without imposing on them an a priori definition of their construction power. Objects do not control social action, which must be accounted for by empirical means. A researcher should be able to follow the trace of prior activities, including references to relevant artefacts. ANT focuses not on isolated objects but on the complex subject-object web of relationships. I use actor-network theory as a working methodology for each of my four virtual archives and in The Assessment installation (Figure 5). For example, I might assign equal importance to the human gesture of transferring chemicals carefully between glass vials and a digital image obtained via measuring some qualities of the different amounts of the substance after the first step/action has been disregarded. Latour described how, for example, a 'tag', such as a simple Post-it note, can become an actor when given figuration. Materiality is consequently vital in the establishment of a relationship. Every Petri dish or MRI scan, or even

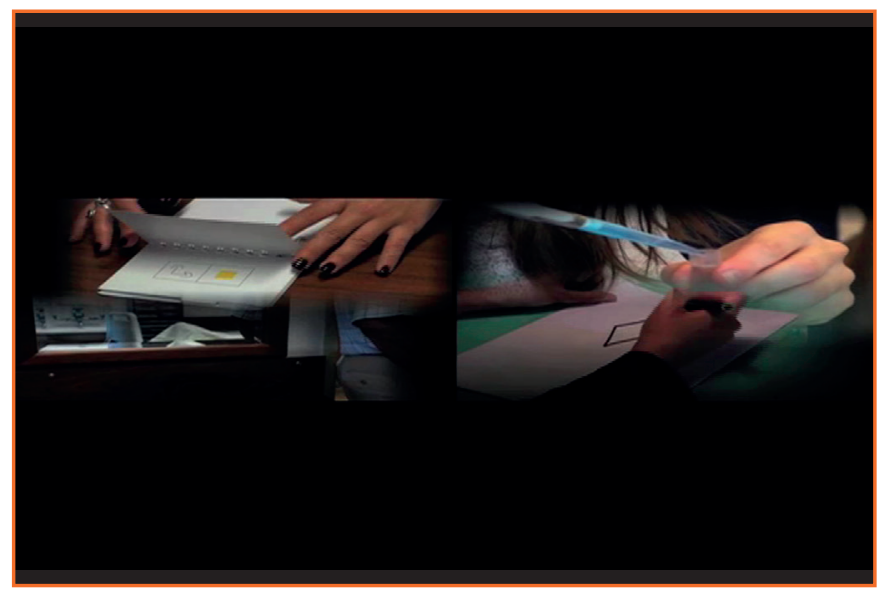

Figure 5. The Assessment. Installation trailer. Video stills, (Lopes, 2011/12). Source: Lopes (2012)
Memory as Material - a visual arts research practice... a light in a room or a postcard on a refrigerator door is a possible event capable of translation. Strength in building science comes from this flux of interactions; 'cascades of inscriptions' which, in turn, become chains of translation.

\section{The Therapy}

There is a compulsion to resist absence by seeking presence; for example, by keeping personal photographs or objects that invoke the presence of a loved one. Process, artefact and object-making could be seen as part of a common attempt to mitigate loss and attachment. Some exercises were carried out in a transitional material such as wax, Plasticine, crayon on paper, talcum powder or ink (Indian ink or scientific dyes for histology procedures) that has a limited life. As an object, it acts as a metaphor for the subtle and decaying nature of memory. Its malleability allows it to be used to illustrate and express ideas and convey meaning in multiple ways that can easily be reused and transformed. In these temporary and constructed spaces, a narrative about absence, loss and memory can be written.

In the process of translation from an orchestrated scientific approach towards the more associative montages of the reenactments, I propose the use of fresh personal narratives or intertwining the imaginary with the real stories of the 'actors' (Latour's term), thus blurring the boundary between the real and the invented and approaching the associative power of autobiographical memory more closely.

I use deceptive and disappearing techniques including paper works, cast wax objects, video fades and semi-erased chalk inscriptions as metaphors for the dialectic relationship of reconstruction and decomposition of memory and the persistence of presence/absence in the memory of the materials. The works produced by these techniques resemble diagrams found in laboratory protocol science manuals, neuropsychological assessments, children's 'how to draw' books and cognitive stimulation therapy exercises. Understood as part of this procedure are forms that are invisible at first but gain substance over time, such as meaning in diagnostic images, as are other forms like laboratory records.

As an exploration of memory, The Therapy (Figure 6) has shown me the potential of productive remembrance, which moves, sees and transforms by ordering the visual in a permanent montage of the archival condition to which we belong. My artworks can evoke but not describe memory, because memory depends on such a personal process of reconstruction. Rather, my artworks are tangible manifestations of change and reconstruction that conceal reenactment and memory. Juxtaposition and montage techniques and processes render the video image unstable, layered, and ambiguous. Image data still carries a residue of my bodily presence, creating 


\section{artnodes}

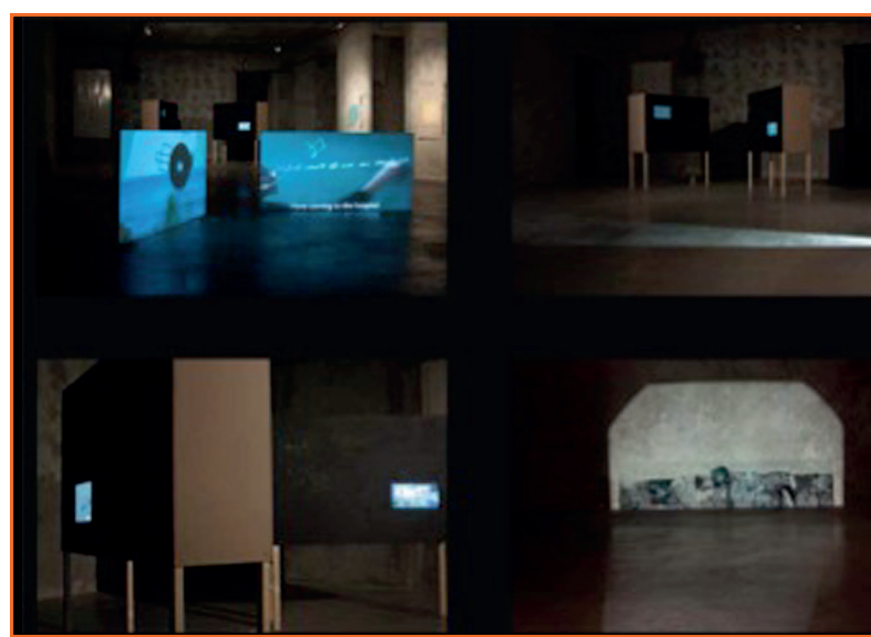

Figure 6. The Therapy. Exhibition Uma coisa entre muitas. Museu Nacional de Historia Natural e da Ciência, Lisbon. Source: Lopes (2012)

an affinity with viewers because it holds a metonymic relationship to their own body. I exploit the material quality of the real brain disappearing by experimenting with the vanishing, dissolution and perpetual becoming of the image through deliberate out-of-focus effects and/or digital manipulation.

Memories, maintained through objects, texts and images, are the physical reminders and remainders of the intangible and provide a temporary place for the containment of our individual experience. In my art practice, the material of the objects has a function in a work through process. The process of repeating the same type of guided exercises was tedious but became obsessive, compelling me to analyse my mnemonic capacities and memory faults. I developed ritualistic working methods such as drawing following the guidelines but using a different type of paper each time. The aesthetic and formal property transformed the repetitive and ritual process of the making. I realised that my aim was not to aestheticize the disease or the science but to find an equivalent form to the experience of the therapy and thereby evoke the functioning of memory itself. I created several parallel experiences of linear, mechanical time passing, but at a different rate from that of the original action and with juxtaposed storylines in an altered order, in tandem with fleeting chalking inscriptions on the supporting black boards. This allows an observer to engage with the tension between performance and repetition, event and memory, that is central to the re-enactment as a representational form. I addressed and explored ways in which recordings and projection (enactment and re-enactment of the archive), both as a concept and as an artistic method, can replicate and extend the medical gaze.

\section{Conclusion}

In the context of my research, I followed the path taken by a patient when approaching the institution (The Approach, The Assessment, The Archive and The Therapy), so that my installations may be understood as an alternative to the representational process of research into, and treatment of, Alzheimer's disease. This creates the potential for an agency to approximate the functioning of autobiographical memory. In the absence of intentional acts of remembering, and irrespective of the expanding scenario of the communication of science and its publications, neuroscientific representational strategies on loss of memory are inert materialities within the scientific universe. It has been demonstrated that, when re-enacted through art practice, these objects become actively able to evoke the way in which memory functions and is subjectively experienced.

\section{Bibliographic references}

BERG, M.;BOWKER, G. (1996). The Multiple Bodies of the Medical Record: Towards a Sociology of an Artefact. [Accessed: 12/11/2010]. <http://www.sis.pitt.edu/ gbowker/records.html> BERG, M.; MOL, A. (eds.) (1998). Differences in Medicine: Unravelling Practices, Techniques and Bodies. USA/Durham, NC: Duke University Press

CASINI, S. (2010). Curating the Biomedical Archive-fever. [Accessed: 20/02/2011]. <http://www.corporeality.net/museion/silvia-casinicurating-the-biomedical-archive-fever/>

CRARY, J. (1992). Techniques of the Observer: On Vision and Modernity in the Nineteenth Century. USA/Cambridge, MA: MIT Press.

CRARY, J. (1999). Suspensions of Perception: Attention, Spectacle, and Modern Culture. USA/Cambridge, MA: MIT Press.

DERRIDA, J. (ed.) (2010). Copy, Archive, Signature:A Conversation on Photography. USA/California: Stanford University Press.

FOUCAULT, M. (1995). Discipline and Punish: The Birth of the Prison. USA/New York, NY: Vintage.

FOUCAULT, M. (2003). The Birth of the Clinic: Archaeology of Medical Perception, Taylor and Francis e-Library.

LATOUR, B. (1987). Science in Action: How to Follow Scientists and Engineers through Society. USA/ Cambridge, MA: Harvard University Press.

LATOUR, B. (1998). "How to Be Iconophilic in Art, Science, and Religion". In: C. A. JONES and P. GALLISON (eds.). Picturing Science, Producing Art, pp. 419-440. Routledge, London,

LATOUR, B. (1999). "On recalling ANT". In: J. LAW and J.HASSARD (eds.). Actor-network and After, UK/0xford: Blackwell. pp. 15-25. $<\mathrm{http}: / /$ dx.doi.org/10.1111/j.1467-954x.1999.tb03480.x>

LATOUR, B. (2005). Reassembling the Social: An Introduction to ActorNetwork-Theory. Uk/0xford: Oxford University Press. 


\section{artnodes}

http://artnodes.uoc.edu

LATOUR, B; and WOOLGAR, S. (1986). Laboratory Life: the Construction of Scientific Facts. USA/Princeton, NJ: Princeton University Press.

LOPES, M. M. (2013). Representational Strategies on Alzheimer's Disease: A Practice-Based Arts Research in a Neuroscience Laboratory (Unpublished doctoral dissertation), University of Brighton and University for the Creative Arts - Farnham, UK.
Memory as Material - a visual arts research practice...

LYNCH, M.; WOOLGAR, S. (1990). "Introduction: Sociological Orientations to Representational Practice in Science". In: LYNCH and WOOLGAR (ed.).Representation in Scientific Practice USA/ Cambridge, MA: MIT Press. pp. 1-18.

STURKEN, M.; CARTWRIGHT, L. (2002). Practices of Looking: an Introduction to Visual Culture (Second Edition). UK/0xford: Oxford University Press.

\section{Recommended citation}

LOPES, Maria Manuela (2015). "Memory as Material - a visual arts research practice in neuroscientific laboratories". In: Pau ALSINA and Ana RODRíGUEZ GRANELL (coord.). "Art Matters II”. Artnodes. №. 16, pp. 17-25. UOC [Accessed: dd/mm/yy].

$<$ http://journals.uoc.edu/ojs/index.php/artnodes/article/view/n16-lopes/n16-lopes-pdf-en> $<$ http://dx.doi.org/10.7238/a.v0i16.2787>

Este artículo está sujeto -si no se indica lo contrario- a una licencia de Reconocimiento 3.0 España de Creative Commons. Puede copiarlos, distribuirlos, comunicarlos públicamente, hacer obras derivadas y usos comerciales siempre que reconozca los créditos de las obras (autoría, nombre de la revista, institución editora) de la manera especificada por los autores o por la revista. La licencia completa se puede consultar en http://creativecommons.org/licenses/by/3.0/es/deed.es. 


\section{artnodes}

http://artnodes.uoc.edu

Memory as Material - a visual arts research practice...

\section{Author}

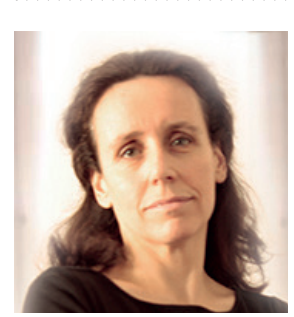

\section{Maria Manuela Lopes}

ID+ Instituto de Investigação em Design Media e Cultura - Universidade de Aveiro

Instituto de Biologia Molecular e Celular- Universidade do Porto, Portugal maria@manuelalopes.com

\section{Rua Pedro Escobar n $90.4 \mathrm{dt}$ 4150-596 Porto, Portugal}

Maria Manuela Lopes is a visual artist and researcher based in Portugal and the UK. Her current practice is transdisciplinary and based on issues of memory and self-identity informed by life sciences and medical research, and presented in the form of time-based installations, occasionally including biological materials.

She has been working and exhibiting nationally and internationally, and also teaching fine arts in Portugal since 1998. She has studied fine arts - sculpture at the FBAUP-Porto, Portugal, and completed an MA at Goldsmiths College in London. She has a Doctorate from Brighton University + UCA Farnham, UK (supervised by de Kathleen Rogers, João Lobo Antunes and Judith Williamson), working with representational strategies of Alzheimer's disease in a neuroscience laboratory at Hospital Santa Maria and Molecular Medicine Institute in Lisbon. She is currently involved in a Post Doctoral project at the Universidade de ID+ and Universidade de Oporto IBMC, under the supervision of Kathleen Rogers, Alexandre Quintanilha and Rosa Oliveira, which extends the $\mathrm{PhD}$ project into a wider cultural scenario questioning what it means to be human in a techno-enhanced society.

Maria is also the Assistant Director of two residency programmes: 1) 'Artists in Labs' Ectopia - Lisbon, and 2) Cultivamos Cultura, an ecological oriented residency programme on a farm in Alentejo. At the same time, she has continued to present her work internationally at conferences and also publish.

\section{$\square$ UOC \\ Universitat Oberta de Catalunya}

